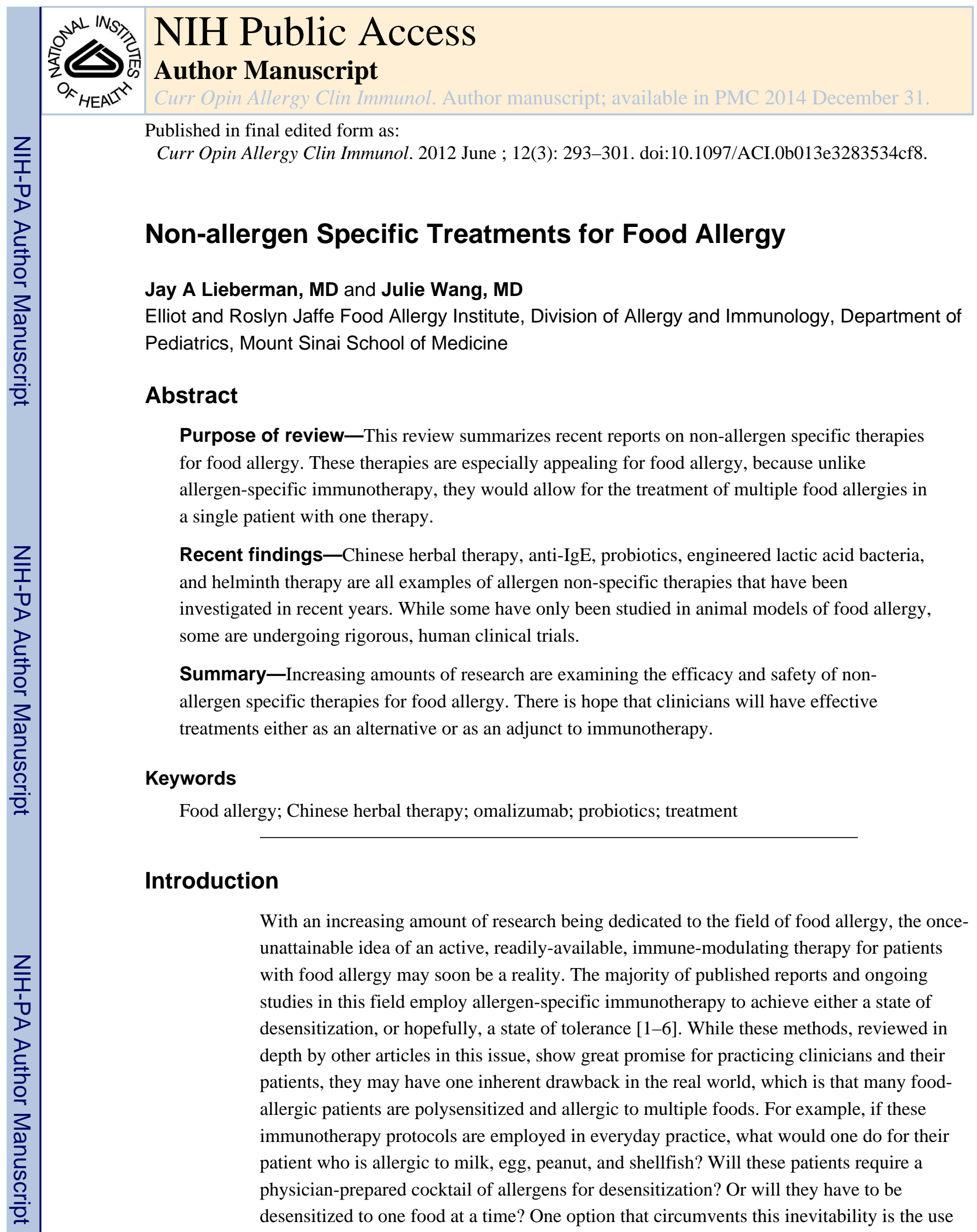

Corresponding author: Julie Wang, MD, One Gustave L. Levy Place, Box 1198, New York, NY 10029, julie.wang@mssm.edu, Phone: 212-241-5548, Fax: 212-426-1902.

Conflicts of interest

Jay Lieberman, MD and Julie Wang, MD have no competing financial interests to disclose. 
of allergen non-specific therapies. The goal of these therapies is to induce a state of tolerance by altering the global host immune response, rather than that specified to a single allergen. While this may be a holy grail in the field of allergy, there are some reports to suggest that we are getting closer, as several non-specific therapies are currently being investigated.

\section{Chinese Herbal Therapy}

While traditional Chinese medicine, which encompasses various practices including herbal therapy, acupuncture, dietary therapy, and mind-body therapy, has been in use for centuries in Asian countries, it is still considered alternative medicine in the Western societies. This stigma is beginning to change, however, as researchers are putting many of these therapies through stringent, scientific trials in order to prove or disprove their efficacy [7]. In the field of allergic diseases, the majority of the randomized controlled clinical trials studying traditional Chinese medicine involve herbal therapies for atopic dermatitis or asthma [8-16]. There are fewer trials studying traditional Chinese medicine in food allergy, although this trend is changing with some promising data in both animal models and in human clinical trials being reported in the last few years.

\section{Murine Model in Food Allergy}

In 2001, Li et al first reported the effects of a formula containing 11 different herbs, termed the Food Allergy Herbal Formula-1 (FAHF-1), in a mouse model of peanut allergy.[17]. The formula was initially based on the herbal therapy, Wu Mei Wan, which has been used to treat gastroenteritis and asthma [18]. In that report, $\mathrm{C} 3 \mathrm{H} / \mathrm{HeJ}$ mice sensitized to peanut were treated with either FAHF-1 or water twice daily for 7 weeks after sensitization. Upon posttherapy peanut challenge, mice treated with FAHF-1 had no symptoms of anaphylaxis, while the sham-treated mice had significantly elevated anaphylaxis scores and had significant decreases in body temperature. This clinical effect was associated with significantly lower plasma histamine levels, lower numbers of degranulated tissue mast cells, and lower levels of peanut-specific serum IgE.

In an attempt to simplify the formula and increase its safety, the researchers later modified FAHF-1 by removing two of the herbs which were potentially toxic if processed improperly. The resultant 9-herb formulation was termed FAHF-2, and its efficacy and safety were studied in the same murine model of peanut anaphylaxis [19]. In that report, FAHF-2 treated mice, unlike sham-treated mice, had no signs of peanut-induced anaphylaxis upon challenge 1 week post therapy. The effect did not appear to be transient, as FAHF-2-treated mice continued to have completely abrogated responses to peanut challenges at 3 and 5 weeks post-therapy, while sham-treated mice continued to exhibit anaphylaxis. This clinical effect was again associated with decreased plasma histamine levels, decreased vascular leakage, decreased peanut-specific IgE levels, and increased peanut-specific IgG2a level.

In a follow-up study of the duration of action, Srivastava et al showed that at 26 weeks posttherapy, all of the FAHF-2 treated mice remained completely protected from anaphylaxis upon peanut challenge, while all of the sham-treated mice exhibited signs of anaphylaxis (including one death) [20]. The effect was persistent at 36 weeks post-therapy, although it 
was not as effective at this point, as 3 of the 8 mice treated with FAHF-2 exhibited moderate allergic reactions.

\section{Mechanism of Action}

The therapeutic effect of FAHF-2 appears to be at least partially dependent upon a shift in immune response from a T helper (Th)-2 response to a Th1 response. All of the murine studies have shown decreases in interleukin (IL)-4, IL-5, and IL-13 levels and increases in interferon-gamma (IFN- $\gamma$ ) from splenocytes or mesenteric lymph node cells of FAHF-2 treated mice [19-21]. The elevated levels of IFN- $\gamma$, later discovered to be the product of CD8+ T cells, appeared to be one of the keys to the formula's effect [21]. In fact, depletion of IFN $-\gamma$ or CD8 $+\mathrm{T}$ cells blocked the suppression of $\mathrm{IgE}$ and $\mathrm{Th} 2$ cytokine responses generated by FAHF-2 [20]. Interestingly, this immune-modulatory effect did not correlate completely with the clinical effect. While the anti-IFN- $\gamma$ antibody could block the Th2 to Th1 shift caused by FAHF-2 throughout treatment, it did not block the clinical effects of FAHF-2 immediately (1 week) post-therapy, rather abrogation of the clinical effects of FAHF-2 by anti-IFN- $\gamma$ were not seen until the second peanut challenge 4 weeks later [20]. The researchers hypothesized that FAHF-2 could therefore be working on mast cells and basophils both through IFN- $\gamma$-dependent and IFN- $\gamma$-independent mechanisms. They went on to show that FAHF-2 treated mice had lower numbers of peripheral blood basophils and peritoneal mast cells than sham-treated controls. In addition, in a mast cell line, FAHF-2 inhibited IgE-stimulated mast cell proliferation and IgE-mediated upregulation of the high affinity IgE receptor (FceRIa) [22]. Therefore, it appeared that FAHF-2 had more than a single mechanism of action, which may reflect the fact that it is a combination of multiple herbs that may have different effects on the immune system.

When examining each herb individually, Kattan et al found that no single herb in the FAHF-2 formula could reproduce the clinical effect of the entire formula [23]. Even when attempting to create a simplified version of the formula using what appeared to be the three most potent ingredients, the authors found that the simplified formula was only partially effective. Therefore, the combination of the 9 herbs in FAHF-2 acting in concert is required to achieve the full effect.

\section{Human Studies}

Based on the success of FAHF-2 in the murine model, studies of the efficacy and safety of FAHF-2 have now been initiated in humans $\left[24^{*}, 25^{* *}\right]$. The initial phase I trial of FAHF-2 examined the safety and dose tolerability of FAHF-2 using a randomized, double-blind, placebo-controlled, dose escalation trial design [24*]. Three doses of FAHF-2 were used: 2.2 grams (4 tablets), 3.3 grams (6 tablets), or 6.6 grams ( 12 tablets), which were taken 3 times daily for 7 days. Overall, the treatment was very well tolerated. Adverse events included one patient in the placebo group reporting vomiting and one patient in the active group reporting loose stools. In addition, one patient in the active arm did withdraw due to a rash, but after evaluation, this was deemed to be a flare of his underlying atopic dermatitis and unlikely related to the medication. Initial immunologic analysis after 7 days of treatment showed no effect on allergen specific IgE levels or skin prick test results, but those in the 
active arm did have significantly lower levels of IL-5 after treatment, which was not seen in the placebo group.

More recently, results of the extended, open-label phase I trial of FAHF-2 have been reported [25**]. In this study, subjects received 3.3 grams ( 6 tablets) of FAHF-2 three times daily for 6 months in order to look at long term safety. Eighteen subjects were enrolled and 14 completed the study, with the reasons for withdrawal being pregnancy (1), difficulty with compliance due to time commitment and number of tablets to swallow (2), and abdominal pain (1). Among the 14 subjects who completed the study, there was only 1 adverse event noted during the 6 months of treatment; this subject had eosinophilic esophagitis thought to be in remission prior to study entry, but experienced a recurrence of symptoms (abdominal pain, dysphagia, and food impaction) during the treatment period. After initiating treatment for her eosinophilic esophagitis, this subject was able to complete the 6 months of FAHF-2. In regard to laboratory findings, there were no changes seen in hematology or chemistry laboratory values, pulmonary function tests, or electrocardiographic findings at baseline, 2 months, 4 months or 6 months of treatment. In this extended phase I trial, the authors also showed some mechanistic data, with evidence of decreased percentages of CD63+ basophils in peripheral blood upon antigen stimulation after 6 months of treatment.

\section{Future endeavors and obstacles}

Currently, a multi-center, double-blind, placebo-controlled phase II trial is ongoing (Clinicaltrials.gov identifier: NCT00602160). In this study, subjects are randomized to receive FAHF-2 or placebo tablets at a dose of 10 tablets three times daily. This large tablet load is a barrier to adherence; therefore, newer extraction techniques are being explored. One such technique, butanol extraction, is able to decrease the effective volume of the compound by approximately 5 fold. The clinical efficacy of this product has been demonstrated in the mouse model [26]. Additional studies are planned to determine the safety of this product in humans.

\section{Anti-IgE Therapy}

The rationale behind the use of anti-IgE therapy for food allergy is no different than for its use in other atopic conditions. By decreasing free serum IgE levels and downregulating the expression of the high-affinity IgE receptor, anti-IgE therapy should theoretically decrease IgE-dependent mast cell and basophil responses to ingested allergen as it does to inhaled allergens.

\section{Initial Study}

Data for the use of anti-IgE therapy in food allergy was first reported in 2003 [27]. In the initial trial, 84 peanut-allergic subjects, 12-64 years of age, were randomized to receive one of 3 doses $(150,300$, and $450 \mathrm{mg}$ ) of a humanized, monoclonal anti-IgE antibody known as TNX-901 (also known as Hu-901) or placebo. All subjects had an entry double-blinded peanut challenge and a post-treatment open peanut challenge 2-4 weeks after completion of therapy. Treatment with TNX-901 increased the eliciting threshold dose of peanut at the post-treatment challenge in a dose-dependent manner, however only the highest dose (450 
mg) produced a statistically significant difference over placebo. Furthermore, the efficacy of this treatment was not uniform for subjects; although $25 \%$ of patients were able to tolerate over 20 peanuts following therapy, another $25 \%$ failed to develop any improvement in tolerance.

\section{Omalizumab and food allergy}

The promising results of the initial anti-IgE therapy in food allergy led to a double-blind trial of the currently commercially available anti-IgE antibody, omalizumab (Xolair®, Genentech), in peanut allergy [28**]. In this trial, peanut allergic subjects (6-75 years old) were randomized to receive either omalizumab or placebo in a 2:1 ratio.

Unfortunately, this study was cut short due to the severity of 2 anaphylactic reactions during the baseline, qualifying peanut challenges (prior to the administration of any study drug). Only 14 subjects completed the trial up to that point ( 9 in the active arm and 5 in the placebo arm). Given that the study was initially powered to enroll 150 subjects, it is not surprising that the data did not reach statistical significance. However, as with the initial trial of antiIgE therapy, omalizumab showed promising results suggesting that anti-IgE can increase the threshold dose required to elicit a reaction. When comparing the baseline tolerable peanut dose to the post-24 week treatment tolerable dose, there was a trend of increased peanut tolerability in the omalizumab-treated subjects compared to the placebo-treated subjects $(\mathrm{P}=$ 0.054). In addition, $44 \%$ of the omalizumab-treated subjects were able to tolerate the goal dose of 1 gram of peanut protein after 24 weeks of treatment compared to only 1 subject in the placebo-treated arm. Thus, it is possible that anti-IgE therapy could decrease the chances of an allergic reaction due to accidental ingestion, but it is unclear whether it could lead to tolerance.

\section{Future directions}

Just as omalizumab has been used as an adjunctive therapy to increase efficacy and decrease adverse reactions with immunotherapy for respiratory allergy [29]. there may be a role for its use as an adjunct to immunotherapy for food allergy. Although there are several promising reports on oral immunotherapy (OIT) for food allergy, this treatment is not without risks. Difficulties with oral and gastrointestinal side effects, as well as systemic allergic reactions have been reported with OIT [30*]. The addition of anti-IgE therapy to food immunotherapy may accelerate the desensitization process while minimizing adverse effects.

Preliminary results have now been published for one such study examining the use of omalizumab in a rush protocol of milk OIT [31]. In this brief communication, the authors showed that treatment with omalizumab 7-11 weeks prior to initiating milk OIT allowed 9 of the 11 enrolled subjects to tolerate the 1-day rush desensitization protocol going from 0.1 $\mathrm{mg}$ to $1000 \mathrm{mg}$ of milk protein. This was a pilot study, lacking a placebo group and baseline double-blinded milk challenge, however, it points to the potential use of omalizumab with food OIT, and there are now ongoing trials currently assessing the use of anti-IgE with OIT to various foods. (Clinicaltrials.gov identifiers: NCT01157117, NCT00932282,

NCT01290913) 


\section{Probiotics and Prebiotics}

Probiotics and prebiotics have been studied at length as a means of both prevention and treatment of atopic diseases. Most of the randomized, clinical trials using probiotics have examined their effects on atopic dermatitis [32-38], however, there are a few studies that have examined their effect on food allergy. Here, we review only those clinical trials that report data on food allergy outcomes since the publication of the most recent review on the topic in this journal [39]. When interpreting these studies, it is important to note that the study population, microorganisms used, doses, and durations of therapy can vary greatly.

\section{Murine Model}

Schiavi et al examined a probiotic mixture of 8 different bacterial strains (Lactobacillus acidophilus, L. delbrueckii, L casei, L plantarum, Bifidobacterium longum. B. infantis, B. breve, and Streptococcus salivarius) in a shrimp tropomyosin-sensitized mouse model [40]. The authors found that treatment with the probiotic mixture after sensitization could decrease anaphylaxis scores upon antigen challenge, with a concomitant decrease in fecal histamine levels as compared to sham-treated controls. This effect was associated with a decrease in tissue levels of Th2 cytokines and an increase in the tissue levels of regulatory cytokines.

\section{Human Studies}

Human studies of probiotics for atopic diseases have not been very conclusive to date, and the most recent Cochrane review of probiotics for eczema concluded that there was evidence to suggest that probiotics were not effective in treating eczema [41]. As stated earlier, there is even less data on their use in food allergy. A recent randomized trial of Lactobacillus GG in an extensively hydrolyzed casein formula (EHCF) compared to EHCF alone demonstrated that infants on the supplemented formula developed tolerance to cow's milk at a faster rate.[42] In perhaps the best trial of probiotics in food allergy to date, Hol et al examined the use of probiotics (Lactobacillus casei and Bifidobacterium lactis, each at $10^{7}$ colony-forming units/gram of formula) in children with diagnosed cow's milk allergy using a randomized, double-blind, placebo-controlled design. The authors showed that there was no difference in the development of tolerance to cow's milk after 6 or 12-months of treatment between the probiotic and placebo groups, based on double-blind, placebocontrolled oral food challenges [43]. In addition, there was no difference in sensitization rates to milk, egg, or soy between the two groups. These findings on sensitization rates are similar to those reported in double-blind, placebo controlled trials of probiotics for eczema that examined sensitization to foods as a secondary endpoint [32,34,35]. In fact, one trial conducted in the Netherlands showed a trend toward an increase in sensitization rates to foods after 1 and 2 years of treatment with probiotics as compared to placebo [35]. Given these data, probiotics do not appear to be a reliable method for prevention or treatment of food allergy at this time [44].

\section{Food Antigen-Expressing, Engineered Probiotic Bacteria}

While lactic acid bacteria (e.g. Lactobacillus and Lactococcus species) have been used in some of the probiotic trials above, these microorganisms are also effective vehicles for 
antigen delivery via genetic engineering, and have been used in a wide array of immunologic and anti-infective strategies [45]. For use in the field of food allergy, these bacteria can be engineered to express various dietary antigens, and in theory, when administered to mucosal sites, these genetically-engineered probiotic bacteria would then deliver the antigen to the mucosa in a Th1-promoting environment.

While no human studies have been reported to date, there have been reports in murine models studying the administration of Lacotcoccus lactis engineered to express $\beta$ lactogolublin ( $\beta$-lac) (milk) and ovalbumin (egg) [46-48] While methods varied in these studies, each reported evidence to suggest that delivery of an adequate amount of antigen to mucosal sites via expression in engineered Lacotcoccus lactis could either treat or prevent sensitization to a target antigen via a shift in the immune response to a Th1 response or via CD4+ CD25+ regulatory T cells expressing transforming growth factor (TGF)- $\beta$.

\section{Cytokine-Expressing, Engineered Probiotic Bacteria}

Instead of engineering Lacotcoccus lactis to express an antigen, some researchers have engineered the bacteria to express regulatory or Th1 cytokines in order to promote tolerance upon administration [49-52]. For example, in one model, Lacotcoccus lactis transfected to secrete IL-10, administered via intragastric gavage prior to sensitization with $\beta$-lac, significantly diminished anaphylactic scores and decreased serum specific IgE levels after challenge with $\beta$-lac [50]. There is also some evidence to suggest that treatment with 2 different strains of Lacotcoccus lactis, one expressing a Th1 cytokine (IL-12 in this case) and the other expressing an antigen of interest, could lead to a synergistic effect not obtained by administering either alone [49].

While these methods using engineered Lacotcoccus lactis to achieve tolerance provide an intriguing model with promising data, they have yet to be studied in humans and are far from clinical use.

\section{Helminth Therapy}

Treatment of inflammatory and allergic conditions with helminth therapy has been a novel approach that has recently garnered public attention. Many reports have shown a negative association of chronic helminth infection and allergic disease, thus forming one of the bases of the hygiene hypothesis [53]. Unfortunately, strong clinical data from rigorous trials on the use of helminth therapy for allergic diseases is sparse, and perhaps the best trial to date, using Trichuris suis ova for allergic rhinitis, did not show any clinical benefit [54]. Many proponents of helminth therapy still have hope that this therapy may be beneficial, and that immunomodulatory products of the worms, rather than simple infection, may provide the benefit [55]. In addition, given one report of the utility of helminth therapy in a murine model of food allergy and it's use in inflammatory bowel disease (another immunologic deviation of the gut) [56,57], there is currently an ongoing trial examining the use of Trichuris suis ova in peanut and tree nut allergy (Clinicaltrials.gov identifier: NCT01070498). 


\section{Conclusion}

While allergen specific immunotherapy appears to hold a bright future in the treatment of food allergy, this treatment is not without risks and may not be efficient for those with multiple food allergies. Therefore, effective allergen non-specific therapies would be an ideal alternative for these individuals as a primary or adjunctive treatment. Various forms of these allergen non-specific therapies are currently under investigation, and some have already shown promising results in human studies. Relevant studies discussed in this review are summarized in Table 1.

\section{Acknowledgments}

Julie Wang, MD is funded in part by a grant from the National Institutes of Health/National Institute of Allergy and Infectious Diseases; AI083883.

\section{References}

1. Skripak JM, Nash SD, Rowley H, Brereton NH, Oh S, Hamilton RG, et al. A randomized, doubleblind, placebo-controlled study of milk oral immunotherapy for cow's milk allergy. J Allergy Clin Immunol. 2008; 122:1154-60. [PubMed: 18951617]

2. Longo G, Barbi E, Berti I, Meneghetti R, Pittalis A, Ronfani L, et al. Specific oral tolerance induction in children with very severe cow's milk-induced reactions. J Allergy Clin Immunol. 2008; 121:343-7. [PubMed: 18158176]

3. Buchanan AD, Green TD, Jones SM, Scurlock AM, Christie L, Althage KA, et al. Egg oral immunotherapy in nonanaphylactic children with egg allergy. J Allergy Clin Immunol. 2007; 119:199-205. [PubMed: 17208602]

4. Clark AT, Islam S, King Y, Deighton J, Anagnostou K, Ewan PW. Successful oral tolerance induction in severe peanut allergy. Allergy. 2009; 64:1218-20. [PubMed: 19226304]

5. Jones SM, Pons L, Roberst JL, Scurlock AM, Perry TT, Kulis M, et al. Clinical efficacy and immune regulation with peanut oral immunotherapy. J Allergy Clin Immunol. 2009; 124:292-300. [PubMed: 19577283]

6. Blumchen K, Ulbricht H, Staden U, Dobberstein K, Beschorner J, de Oliveira LC, et al. Oral peanut immunotherapy in children with peanut anaphylaxis. J Allergy Clin Immunol. 2010; 126:83-91. [PubMed: 20542324]

7. Jiang M, Yang J, Zhang C, Liu B, Chan K, Cao H, Lu A. Clinical studies with traditional Chinese medicine in the past decade and future research and development. Planta Med. 2010; 76:2048-2064. [PubMed: 20979016]

8. Chan CK, Kuo ML, Shen JJ, See LC, Chang HH, Huang JL. Ding Chuan Tang, a Chinese herb decoction, could improve airway hyper-responsiveness in stabilized asthmatic children: a randomized, double-blind clinical trial. Pediatr Allergy Immunol. 2006; 17:316-322. [PubMed: 16846448]

9. Cheng HM, Chiang LC, Jan YM, Chen GW, Li TC. The efficacy and safety of a Chinese herbal product (Xiao-Feng-San) for the treatment of refractory atopic dermatitis: a randomized, doubleblind, placebo-controlled trial. Int Arch Allergy Immunol. 2011; 155:141-148. [PubMed: 21196758]

10. Hon KL, Leung TF, Ng PC, Lam MC, Kam WY, Wong KY, Lee KC, Sung YT, Cheng KF, Fok $\mathrm{TF}$, et al. Efficacy and tolerability of a Chinese herbal medicine concoction for treatment of atopic dermatitis: a randomized, double-blind, placebo-controlled study. Br J Dermatol. 2007; 157:357363. [PubMed: 17501956]

11. Hsu CH, Lu CM, Chang TT. Efficacy and safety of modified Mai-Men-Dong-Tang for treatment of allergic asthma. Pediatr Allergy Immunol. 2005; 16:76-81. [PubMed: 15693916]

12. Kelly-Pieper K, Patil SP, Busse P, Yang N, Sampson H, Li XM, Wisnivesky JP, Kattan M. Safety and tolerability of an antiasthma herbal Formula (ASHMI) in adult subjects with asthma: a 
randomized, double-blinded, placebo-controlled, dose-escalation phase I study. J Altern Complement Med. 2009; 15:735-743. [PubMed: 19586409]

13. Sheehan MP, Rustin MH, Atherton DJ, Buckley C, Harris DW, Brostoff J, Ostlere L, Dawson A. Efficacy of traditional Chinese herbal therapy in adult atopic dermatitis. Lancet. 1992; 340:13-17. [PubMed: 1351600]

14. Urata Y, Yoshida S, Irie Y, Tanigawa T, Amayasu H, Nakabayashi M, Akahori K. Treatment of asthma patients with herbal medicine TJ-96: a randomized controlled trial. Respir Med. 2002; 96:469-474. [PubMed: 12117049]

15. Wen MC, Wei CH, Hu ZQ, Srivastava K, Ko J, Xi ST, Mu DZ, Du JB, Li GH, Wallenstein S, et al. Efficacy and tolerability of anti-asthma herbal medicine intervention in adult patients with moderate-severe allergic asthma. J Allergy Clin Immunol. 2005; 116:517-524. [PubMed: 16159618]

16. Wong EL, Sung RY, Leung TF, Wong YO, Li AM, Cheung KL, Wong CK, Fok TF, Leung PC. Randomized, double-blind, placebo-controlled trial of herbal therapy for children with asthma. J Altern Complement Med. 2009; 15:1091-1097. [PubMed: 19821718]

17. Li XM, Zhang TF, Huang CK, Srivastava K, Teper AA, Zhang L, Schofield BH, Sampson HA. Food Allergy Herbal Formula-1 (FAHF-1) blocks peanut-induced anaphylaxis in a murine model. J Allergy Clin Immunol. 2001; 108:639-646. [PubMed: 11590394]

18. Bensky, D.; Barolet, R. Chinese herbal medicine: formulas \& strategies. Seattle: Eastland Press; 1990.

19. Srivastava KD, Kattan JD, Zou ZM, Li JH, Zhang L, Wallenstein S, Goldfarb J, Sampson HA, Li $\mathrm{XM}$. The Chinese herbal medicine formula FAHF-2 completely blocks anaphylactic reactions in a murine model of peanut allergy. J Allergy Clin Immunol. 2005; 115:171-178. [PubMed: 15637565]

20. Srivastava KD, Qu C, Zhang T, Goldfarb J, Sampson HA, Li XM. Food Allergy Herbal Formula-2 silences peanut-induced anaphylaxis for a prolonged posttreatment period via IFN-gammaproducing CD8+ T cells. J Allergy Clin Immunol. 2009; 123:443-451. [PubMed: 19203662]

21. Qu C, Srivastava K, Ko J, Zhang TF, Sampson HA, Li XM. Induction of tolerance after establishment of peanut allergy by the food allergy herbal formula- 2 is associated with upregulation of interferon-gamma. Clin Exp Allergy. 2007; 37:846-855. [PubMed: 17517098]

22. Song Y, Qu C, Srivastava K, Yang N, Busse P, Zhao W, Li XM. Food allergy herbal formula 2 protection against peanut anaphylactic reaction is via inhibition of mast cells and basophils. $\mathrm{J}$ Allergy Clin Immunol. 2010; 126:1208-1217. e1203. [PubMed: 21134573]

23. Kattan JD, Srivastava KD, Zou ZM, Goldfarb J, Sampson HA, Li XM. Pharmacological and immunological effects of individual herbs in the Food Allergy Herbal Formula-2 (FAHF-2) on peanut allergy. Phytother Res. 2008; 22:651-659. [PubMed: 18389474]

24*. Wang J, Patil SP, Yang N, Ko J, Lee J, Noone S, Sampson HA, Li XM. Safety, tolerability, and immunologic effects of a food allergy herbal formula in food allergic individuals: a randomized, double-blinded, placebo-controlled, dose escalation, phase 1 study. Ann Allergy Asthma Immunol. 2010; 105:75-84. The first safety trial of FAHF-2 in humans that shows short term safety of FAHF-2. [PubMed: 20642207]

25. Clinical safety of Food Allergy Herbal Formula-2 (FAHF-2) and inhibitory effect on basophils from patients with food allergy: Extended phase I study. J Allergy Clin Immunol. 2011 Reports results from extended phase I safety trial of FAHF-2 in humans that suggests the treatment has an excellent safety profile. In addition, the authors show early mechanistic data from this human trial.

26. Srivastava K, Yang N, Chen Y, Lopez-Exposito I, Song Y, Goldfarb J, Zhan J, Sampson H, Li XM. Efficacy, safety and immunological actions of butanol-extracted Food Allergy Herbal Formula-2 on peanut anaphylaxis. Clin Exp Allergy. 2011; 41:582-591. [PubMed: 21121976]

27. Leung DY, Sampson HA, Yunginger JW, Burks AW Jr, Schneider LC, Wortel CH, Davis FM, Hyun JD, Shanahan WR Jr. Effect of anti-IgE therapy in patients with peanut allergy. N Engl J Med. 2003; 348:986-993. [PubMed: 12637608]

28**. Sampson HA, Leung DY, Burks AW, Lack G, Bahna SL, Jones SM, Wong DA. A phase II, randomized, doubleblind, parallelgroup, placebocontrolled oral food challenge trial of Xolair (omalizumab) in peanut allergy. J Allergy Clin Immunol. 2011; 127:1309-1310. e1301. 
Attempted large-scale randomized study of anti-IgE therapy for peanut allergy in humans cut short due to reactions during peanut challenges prior to randomization. [PubMed: 21397314]

29. Kopp MV. Role of immunmodulators in allergen-specific immunotherapy. Allergy. 2011; 66:792797. [PubMed: 21332502]

30. Varshney P, Jones SM, Scurlock AM, Perry TT, Kemper A, Steele P, Hiegel A, Kamilaris J, Carlisle S, Yue X, et al. A randomized controlled study of peanut oral immunotherapy: clinical desensitization and modulation of the allergic response. J Allergy Clin Immunol. 2011; 127:654660. [PubMed: 21377034]

31*. Nadeau KC, Schneider LC, Hoyte L, Borras I, Umetsu DT. Rapid oral desensitization in combination with omalizumab therapy in patients with cow's milk allergy. J Allergy Clin Immunol. 2011; 127:1622-1624. Pilot study suggesting possible role of anti-IgE therapy as an adjunct to oral immunotherapy for food allergy. [PubMed: 21546071]

32. Boyle RJ, Ismail IH, Kivivuori S, Licciardi PV, Robins-Browne RM, Mah LJ, Axelrad C, Moore S, Donath S, Carlin JB, et al. Lactobacillus GG treatment during pregnancy for the prevention of eczema: a randomized controlled trial. Allergy. 2010; 66:509-516. [PubMed: 21121927]

33. Dotterud CK, Storro O, Johnsen R, Oien T. Probiotics in pregnant women to prevent allergic disease: a randomized, double-blind trial. Br J Dermatol. 2010; 163:616-623. [PubMed: 20545688]

34. Kim JY, Kwon JH, Ahn SH, Lee SI, Han YS, Choi YO, Lee SY, Ahn KM, Ji GE. Effect of probiotic mix (Bifidobacterium bifidum, Bifidobacterium lactis, Lactobacillus acidophilus) in the primary prevention of eczema: a double-blind, randomized, placebo-controlled trial. Pediatr Allergy Immunol. 2009; 21:e386-393. [PubMed: 19840300]

35. Niers L, Martin R, Rijkers G, Sengers F, Timmerman H, van Uden N, Smidt H, Kimpen J, Hoekstra M. The effects of selected probiotic strains on the development of eczema (the PandA study). Allergy. 2009; 64:1349-1358. [PubMed: 19392993]

36. Rose MA, Stieglitz F, Koksal A, Schubert R, Schulze J, Zielen S. Efficacy of probiotic Lactobacillus GG on allergic sensitization and asthma in infants at risk. Clin Exp Allergy. 40:1398-1405. [PubMed: 20604800]

37. West CE, Hammarstrom ML, Hernell O. Probiotics during weaning reduce the incidence of eczema. Pediatr Allergy Immunol. 2009; 20:430-437. [PubMed: 19298231]

38. Kuitunen M, Kukkonen K, Juntunen-Backman K, Korpela R, Poussa T, Tuure T, Haahtela T, Savilahti E. Probiotics prevent IgE-associated allergy until age 5 years in cesarean-delivered children but not in the total cohort. J Allergy Clin Immunol. 2009; 123:335-341. [PubMed: 19135235]

39. Savilahti E, Kuitunen M, Vaarala O. Pre and probiotics in the prevention and treatment of food allergy. Curr Opin Allergy Clin Immunol. 2008; 8:243-248. [PubMed: 18560300]

40. Schiavi E, Barletta B, Butteroni C, Corinti S, Boirivant M, Di Felice G. Oral therapeutic administration of a probiotic mixture suppresses established Th2 responses and systemic anaphylaxis in a murine model of food allergy. Allergy. 2011; 66:499-508. [PubMed: 21058959]

41. Boyle RJ, Bath-Hextall FJ, Leonardi-Bee J, Murrell DF, Tang ML. Probiotics for treating eczema. Cochrane Database Syst Rev. 2008:CD006135. [PubMed: 18843705]

42. Canani RB, Nocerino R, Terrin G, Coruzzo A, Cosenza L, Leone L, Troncone R. Effect of Lactobacillus GG on tolerance acquisition in infants with cow's milk allergy: A randomized trial. J Allergy Clin Immunol. 2012; 129:580-82. [PubMed: 22078573]

43. Hol J, van Leer EH, Elink Schuurman BE, de Ruiter LF, Samsom JN, Hop W, Neijens HJ, de Jongste JC, Nieuwenhuis EE. The acquisition of tolerance toward cow's milk through probiotic supplementation: a randomized, controlled trial. J Allergy Clin Immunol. 2008; 121:1448-1454. [PubMed: 18436293]

44. WAO Special Committee on Food Allergy. The clinical use of probiotics for paediatric allergy (CUPPA). WAO. 2012

45. Wells JM, Mercenier A. Mucosal delivery of therapeutic and prophylactic molecules using lactic acid bacteria. Nat Rev Microbiol. 2008; 6:349-362. [PubMed: 18345021] 
46. Adel-Patient K, Ah-Leung S, Creminon C, Nouaille S, Chatel JM, Langella P, Wal JM. Oral administration of recombinant Lactococcus lactis expressing bovine beta-lactoglobulin partially prevents mice from sensitization. Clin Exp Allergy. 2005; 35:539-546. [PubMed: 15836765]

47. Cortes-Perez NG, Ah-Leung S, Bermudez-Humaran LG, Corthier G, Langella P, Wal JM, AdelPatient K. Allergy therapy by intranasal administration with recombinant Lactococcus lactis Producing bovine beta-lactoglobulin. Int Arch Allergy Immunol. 2009; 150:25-31. [PubMed: 19339799]

48. Huibregtse IL, Snoeck V, de Creus A, Braat H, De Jong EC, Van Deventer SJ, Rottiers P. Induction of ovalbumin-specific tolerance by oral administration of Lactococcus lactis secreting ovalbumin. Gastroenterology. 2007; 133:517-528. [PubMed: 17681173]

49. Cortes-Perez NG, Ah-Leung S, Bermudez-Humaran LG, Corthier G, Wal JM, Langella P, AdelPatient K. Intranasal coadministration of live lactococci producing interleukin-12 and a major cow's milk allergen inhibits allergic reaction in mice. Clin Vaccine Immunol. 2007; 14:226-233. [PubMed: 17202306]

50. Frossard CP, Steidler L, Eigenmann PA. Oral administration of an IL-10-secreting Lactococcus lactis strain prevents food-induced IgE sensitization. J Allergy Clin Immunol. 2007; 119:952-959. [PubMed: 17316776]

51. Marinho FA, Pacifico LG, Miyoshi A, Azevedo V, Le Loir Y, Guimaraes VD, Langella P, Cassali GD, Fonseca CT, Oliveira SC. An intranasal administration of Lactococcus lactis strains expressing recombinant interleukin-10 modulates acute allergic airway inflammation in a murine model. Clin Exp Allergy. 2010; 40:1541-1551. [PubMed: 20412136]

52. Wu C, Yang G, Bermudez-Humaran LG, Pang Q, Zeng Y, Wang J, Gao X. Immunomodulatory effects of IL-12 secreted by Lactococcus lactis on Th1/Th2 balance in ovalbumin (OVA)-induced asthma model mice. Int Immunopharmacol. 2006; 6:610-615. [PubMed: 16504924]

53. Flohr C, Quinnell RJ, Britton J. Do helminth parasites protect against atopy and allergic disease? Clin Exp Allergy. 2009; 39:20-32. [PubMed: 19128351]

54. Bager P, Arnved J, Ronborg S, Wohlfahrt J, Poulsen LK, Westergaard T, Petersen HW, Kristensen B, Thamsborg S, Roepstorff A, et al. Trichuris suis ova therapy for allergic rhinitis: a randomized, double-blind, placebo-controlled clinical trial. J Allergy Clin Immunol. 2010; 125:123-130. e121123. [PubMed: 19800680]

55. Hepworth MR, Hamelmann E, Lucius R, Hartmann S. Looking into the future of Trichuris suis therapy. J Allergy Clin Immunol. 125:767-768. author reply 768-769. [PubMed: 20153034]

56. Bashir ME, Andersen P, Fuss IJ, Shi HN, Nagler-Anderson C. An enteric helminth infection protects against an allergic response to dietary antigen. J Immunol. 2002; 169:3284-3292. [PubMed: 12218148]

57. Summers RW, Elliott DE, Urban JF Jr, Thompson R, Weinstock JV. Trichuris suis therapy in Crohn's disease. Gut. 2005; 54:87-90. [PubMed: 15591509] 


\section{Key Points}

- The Food Allergy Herbal Formula 2 (FAHF-2) is a Chinese herbal therapy that has been shown to abrogate anaphylaxis in a mouse model of peanut anaphylaxis, and is now being investigated in a phase II efficacy trial in humans.

- Early studies with anti-IgE therapy appeared to confer increased tolerance in only a subset of peanut-allergic subjects. More recent studies are exploring its use as an adjunct to food-allergen immunotherapy.

- Probiotics have been studied extensively in atopic disease, and while they may improve atopic dermatitis is some patients, they do not currently have a role in the prevention or treatment of food allergy.

- Lactic acid bacteria engineered to express food allergens and/or cytokines that dampen or shift the allergic immune response have been shown to have potential in the treatment of food allergy in a mouse model.

- Data on the treatment of atopic disease with helminth therapy, namely Trichuris suis ova, has been controversial, however, reports from its use in inflammatory bowel disease and in murine models of food anaphylaxis provide hope for its success in food allergy. 
Table 1

Summary of selected allergen non-specific therapy publications

\begin{tabular}{|c|c|c|c|c|}
\hline Therapy Type & Publication & Model & Study and Treatment Goal & Findings and Summary \\
\hline \multirow{6}{*}{ Chinese Herbal Therapy } & $\begin{array}{c}\text { Li et al } \\
2001[11]\end{array}$ & $\frac{\text { Mouse }}{\text { Peanut }}$ & FAHF-1 Treatment & $\begin{array}{l}\text { Mice in active group had: } \\
\text { - } \quad \text { Decreased anaphylaxis } \\
\text { score } \\
\text { - } \\
\text { Lower plasma } \\
\text { histamine levels } \\
\text { - } \quad \begin{array}{c}\text { Lower numbers of } \\
\text { degranulated tissue } \\
\text { mast cells }\end{array} \\
\text { - } \quad \text { Lower peanut sIgE }\end{array}$ \\
\hline & $\begin{array}{l}\text { Srivastava et } \\
\text { al 2005[13] }\end{array}$ & $\frac{\text { Mouse }}{\text { Peanut }}$ & FAHF-2 Treatment & 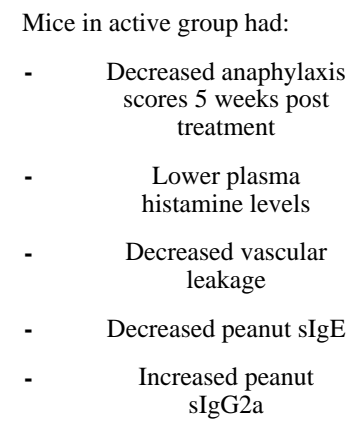 \\
\hline & $\begin{array}{l}\text { Srivastava et } \\
\text { al 2009[14] }\end{array}$ & $\frac{\text { Mouse }}{\text { Peanut }}$ & FAHF-2 Treatment & $\begin{array}{l}\text { Mice in active group had: } \\
\text { - } \quad \begin{array}{c}\text { Decreased anaphylaxis } \\
\text { scores } 26 \text { weeks post } \\
\text { treatment }\end{array} \\
\text { - } \quad \begin{array}{c}\text { Effect appeared IFN- } \gamma \\
\text { dependent in part }\end{array}\end{array}$ \\
\hline & $\begin{array}{l}\text { Song et al } \\
2010[16]\end{array}$ & $\frac{\text { Mouse }}{\text { Peanut }}$ & FAHF-2 Treatment & $\begin{array}{c}\text { Mice in active group had: } \\
\text { - } \quad \begin{array}{c}\text { Decreased anaphylaxis } \\
\text { scores } 4 \text { weeks post- } \\
\text { therapy }\end{array} \\
\text { - } \quad \begin{array}{c}\text { Decreased numbers } \\
\text { peripheral blood } \\
\text { basophils }\end{array} \\
\text { - } \quad \begin{array}{c}\text { Decreased numbers of } \\
\text { peritoneal mast cells }\end{array} \\
\text { - Decreased expression } \\
\text { of FceRI on peritoneal } \\
\text { mast cells }\end{array}$ \\
\hline & $\begin{array}{l}\text { Wang et al } \\
2010[18]\end{array}$ & $\frac{\text { Human }}{\text { Multiple foods }}$ & $\begin{array}{l}\text { FAHF-2 RDBPC Treatment Phase } \\
\text { I Dosing study }\end{array}$ & $\begin{array}{c}\text { Initial safety trial in humans: } \\
\text { - } \quad \text { Minimal side effects } \\
\text { seen after one week of } \\
\text { treatment }\end{array}$ \\
\hline & $\begin{array}{l}\text { Patil et al } \\
\text { 2011[19] }\end{array}$ & $\underset{\text { Multiple foods }}{\text { Human }}$ & $\begin{array}{l}\text { FAHF-2 RDBPC Treatment } \\
\text { Extended Phase I study }\end{array}$ & $\begin{array}{c}\text { Extended safety trial: } \\
\text { - } \quad \text { Only } 1 \text { reported } \\
\text { adverse event after } 6\end{array}$ \\
\hline
\end{tabular}




\begin{tabular}{|c|c|c|c|c|}
\hline Therapy Type & Publication & Model & Study and Treatment Goal & Findings and Summary \\
\hline & & & & $\begin{array}{c}\text { months of treatment in } \\
14 \text { patients } \\
\text { Decreased percentage } \\
\text { of CD63+ basophils in } \\
\text { peripheral blood upon } \\
\text { antigen stimulation } \\
\text { after } 6 \text { months of } \\
\text { treatment }\end{array}$ \\
\hline & $\begin{array}{l}\text { Leung et al } \\
2003[21]\end{array}$ & $\frac{\text { Human }}{\text { Peanut }}$ & $\begin{array}{l}\text { TNX-901 RDBPC Treatment } \\
\text { dosing study }\end{array}$ & $\begin{array}{c}\text { The highest dose ( } 450 \\
\text { mg) given every } 4 \\
\text { weeks for } 4 \text { doses } \\
\text { significantly increased } \\
\text { peanut threshold doses } \\
\text { over baseline as } \\
\text { compared to placebo }\end{array}$ \\
\hline Anti-IgE Therapy & $\begin{array}{l}\text { Sampson et al } \\
2011[22]\end{array}$ & $\frac{\text { Human }}{\text { Peanut }}$ & Omalizumab RDBPC Treatment & 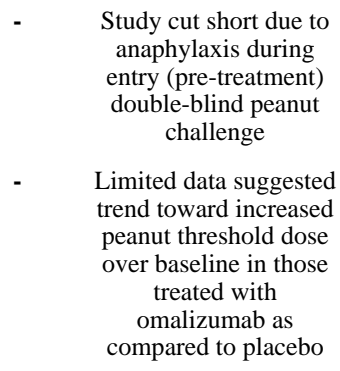 \\
\hline \multirow{5}{*}{ Probiotics } & $\begin{array}{l}\text { Schiavi et al } \\
\text { 2011[34] }\end{array}$ & $\frac{\text { Mouse }}{\text { Shrimp }}$ & $\begin{array}{c}\text { Probiotic mixture of } 8 \text { strains } \\
\text { Treatment }\end{array}$ & $\begin{array}{l}\text { Mice in active group had: } \\
\text { - } \quad \text { Decreased anaphylaxis } \\
\text { score } \\
\text { - } \quad \text { Lower fecal histamine } \\
\text { levels } \\
\text { - } \quad \text { Lower levels of jejunal } \\
\text { Th2 cytokines }\end{array}$ \\
\hline & $\begin{array}{l}\text { Hol et al } \\
2008[36]\end{array}$ & $\begin{array}{l}\text { Human } \\
\text { Infants younger } \\
\text { than } 6 \text { month } \\
\text { with milk } \\
\text { allergy }\end{array}$ & $\begin{array}{l}\text { Probiotic mixture of } 2 \text { strains } \\
\text { RDBPC Treatment }\end{array}$ & $\begin{array}{c}\text { - } \\
\text { No difference in } \\
\text { development of } \\
\text { tolerance in treatment } \\
\text { versus placebo groups } \\
\text { after } 6 \text { and } 12 \text { months. } \\
\text { No difference in egg or } \\
\text { soy sensitization rates } \\
\text { in the } 2 \text { treatment } \\
\text { groups }\end{array}$ \\
\hline & $\begin{array}{l}\text { Kim et al } \\
2009[28]\end{array}$ & $\begin{array}{l}\text { Human } \\
\text { Pregnant } \\
\text { women with } \\
\text { family history } \\
\text { of allergic } \\
\text { disease }\end{array}$ & $\begin{array}{l}\text { Probiotic mixure of } 3 \text { strains } \\
\text { RDBPC Prophylaxis }\end{array}$ & $\begin{array}{l}\text { No difference in food } \\
\text { sensitization or } \\
\text { "probable" food allergy } \\
\text { in treatment versus } \\
\text { placebo groups after 1 } \\
\text { year }\end{array}$ \\
\hline & $\begin{array}{l}\text { Niers et al } \\
2009[29]\end{array}$ & $\begin{array}{l}\text { Human } \\
\text { Pregnant } \\
\text { women with } \\
\text { family history } \\
\text { of allergic } \\
\text { disease }\end{array}$ & $\begin{array}{l}\text { Probiotic mixure of } 3 \text { strains } \\
\text { RDBPC Prophylaxis }\end{array}$ & $\begin{array}{l}\text { No difference in food } \\
\text { sensitization in } \\
\text { treatment versus } \\
\text { placebo after } 1 \text { and } 2 \\
\text { years }\end{array}$ \\
\hline & $\begin{array}{l}\text { Boyle et al } \\
2010[26]\end{array}$ & $\underline{\text { Human }}$ & $\begin{array}{c}\text { Probiotic of single strain RDBPC } \\
\text { Prophylaxis }\end{array}$ & $\begin{array}{c}\text { No difference in food } \\
\text { sensitization in }\end{array}$ \\
\hline
\end{tabular}




\begin{tabular}{|c|c|c|c|c|}
\hline Therapy Type & Publication & Model & Study and Treatment Goal & Findings and Summary \\
\hline & & $\begin{array}{c}\text { Pregnant } \\
\text { women with } \\
\text { family history } \\
\text { of allergic } \\
\text { disease }\end{array}$ & & $\begin{array}{l}\text { treatment versus } \\
\text { placebo after } 1 \text { year }\end{array}$ \\
\hline $\begin{array}{c}\text { Engineered Lactic Acid } \\
\text { Bacteria }\end{array}$ & $\begin{array}{l}\text { Frossard et al } \\
2007\end{array}$ & $\stackrel{\text { Mouse }}{\text { Milk ( } \beta \text {-lac) }}$ & $\begin{array}{l}\text { IL-10 secreting } L \text {. lactis } \\
\text { Prophylaxis }\end{array}$ & $\begin{array}{c}\text { Mice pretreated with } \\
\text { IL-10 secreting L. } \\
\text { lactis had lower } \\
\text { anaphylaxis scores } \\
\text { upon challenge with } \beta \text { - } \\
\text { lac }\end{array}$ \\
\hline Helminth Therapy & $\begin{array}{l}\text { Bashir et al } \\
\quad 2002\end{array}$ & $\frac{\text { Mouse }}{\text { Peanut }}$ & $\begin{array}{l}\text { H polygyrus infected mice } \\
\text { Prophylaxis }\end{array}$ & $\begin{array}{c}\text { H polygyrus infection prior to } \\
\text { sensitization led to: } \\
-\quad \text { Decreased anaphylaxis } \\
\text { scores } \\
-\quad \text { Lower plasma } \\
\text { histamine levels } \\
\text { - } \\
\text { Lffects were attenuated with anti- } \\
\text { IL-10 }\end{array}$ \\
\hline
\end{tabular}

sIgE $=$ specific IgE, FAHF $=$ Food allergy herbal formula, IFN- $\gamma=$ Interferon gamma, RDBPC $=$ Randomized double-blind placebo-controlled trial, IL=Interleukin 